\title{
SHRIMP U-PB DATING OF A PEROVSKITE INCLUSION IN DIAMOND: EVIDENCE FOR A SYNERUPTION AGE FOR DIAMOND FORMATION, SYTYKANSKAYA KIMBERLITE PIPE, YAKUTIA REGION, SIBERIA
}

\author{
Michael A. Hamilton ${ }^{1}$, Nikolai V. Sobolev ${ }^{2}$, Richard A. Stern ${ }^{1}$ and D. Graham Pearson ${ }^{3}$ \\ ${ }^{1}$ Geol. Survey of Canada, Canada; ${ }^{2}$ Russian Acad. Sciences, Russia $;{ }^{3}$ Geological Sciences, Durham University, UK
}

\section{INTRODUCTION}

The relationship between diamonds and host kimberlites has been a controversial topic since the first diamond discoveries. Initial dating of syngenetic inclusions within diamonds revealed that some diamonds of peridotitic paragenesis were significantly older than their host kimberlite (e.g. Richardson et al., 1984). While these and later studies argued strongly for an ancient origin for many peridotitic diamonds, some recent studies have suggested that certain diamonds of eclogitic paragenesis (Richardson, 1986; Burgess et al., 1989; Phillips et al., 1989; Taylor et al., 1998) and even some of peridotitic paragenesis (Shimizu \& Sobolev, 1995; Pearson et al., 1998) could be of similar age to their host kimberlites. Resolving these issues in important for diamond genesis models.

Early studies, by necessity, analysed multi-grain composites to produce model ages (Richardson et al., 1984; 1990; 1993). However, recent technological advances allow single inclusion dating of either sulfides (Pearson et al., 1998) or phases suitable for U-Pb geochronology (Kinny and Meyer, 1994). Even single sulfide analyses, where only model age constraints are available, are subject to the uncertainty of whether the sulfide has been surrounded by a later diamond, as suggested by Spetsius et al. (2002). Direct U-Pb dating of relatively high- $U$ phases such as zircon and perovskite does not suffer from such conceptual uncertainties and assumptions due to the attributes of the $\mathrm{U}-\mathrm{Pb}$ chronometer in these minerals. A perhaps larger obstacle exists in the scarcity of these minerals as inclusions within diamonds themselves. Kinny and Meyer (1994) reported the only published U-Pb age to date on a zircon included in a diamond, from kimberlite at Mbuji Mayi, Zaire (Democratic Republic of Congo). These authors made use of non-destructive SHRIMP (sensitive high resolution ion microprobe) methods to define a $628 \mathrm{Ma}$ age for the zircon and, by inference, its syngenetic diamond host, significantly older than the kimberlite pipe emplacement age $(71 \mathrm{Ma})$. In the present study, we present the first application of the U$\mathrm{Pb}$ dating system to a single perovskite inclusion within diamond. The results further underscore the potential of $\mathrm{U}(-\mathrm{Th})-\mathrm{Pb}$ dating of suitably radiogenic mineral inclusions and provide encouragement for mounting efforts to obtain additional specimens or finding ways to improve our ability to recognise such inclusions.

\section{RESULTS}

\section{SAMPLE DESCRIPTION}

The utility of direct $\mathrm{U}-\mathrm{Pb}$ dating of groundmass perovskite, by conventional means or SHRIMP, in studying kimberlite magmatism is well established (Bristow et al., 1991; Smith et al., 1994; Heaman and Mitchell, 1995; Kinny et al., 1997) but the technique has not been applied to perovskite inclusions within diamond because of their extreme rarity among inclusion populations. During a study of diamonds from the Sytykanskaya kimberlite pipe of the Alakit region of Yakutia, an octahedral diamond weighing approximately $7.1 \mathrm{mg}$ was discovered to contain a number of isolated individual opaque inclusions, including five discrete chromites (with 0.21-0.29 wt.\% $\left.\mathrm{TiO}_{2}\right)$, one olivine grain $\left(\mathrm{Fo}_{93.1}\right)$, and a single perovskite inclusion $(<100$ microns), confirmed by microprobe analysis. To our knowledge, the only other perovskite inclusions identified within diamond appear to be epigenetic in origin (Meyer, 1987; Kopylova et al., 1997). In the diamond studied here, all inclusions showed characteristic negative crystal faceting, and optical and cathodoluminescence studies revealed no cracks or healed cracks leading to the perovskite. These physical traits are commonly used to infer that an inclusion may be syngenetic in origin (Bulanova, 1995). Furthermore, the perovskite inclusion in the Sytykanskaya diamond has elevated $\mathrm{Cr}$, and associated chromites have enriched $\mathrm{Ti}$ contents, suggesting equilibrium between the two phases. The above evidence suggests that this perovskite is a syngenetic inclusion that grew with the diamond. 


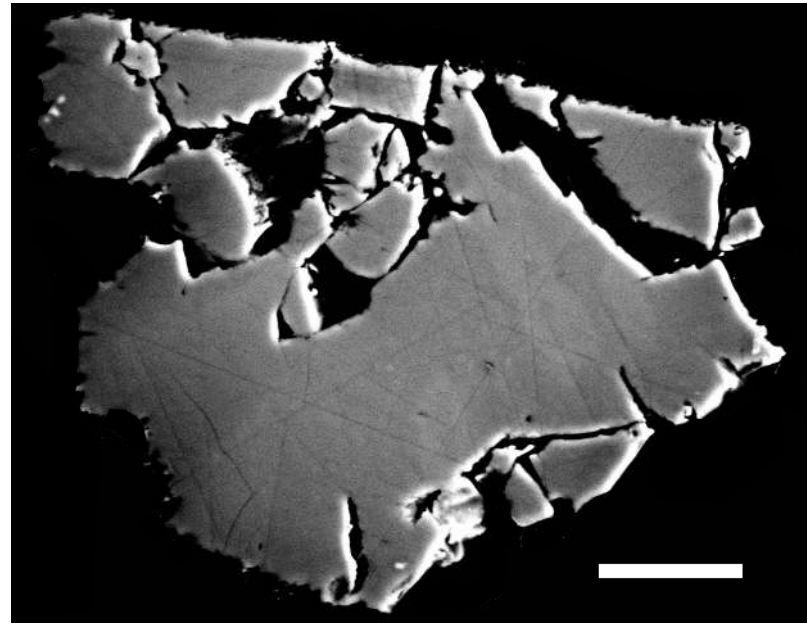

Figure 1: Backscattered electron image of perovskite inclusion from Sytykanskaya diamond. Scale bar is $20 \mu \mathrm{m}$.

\section{SHRIMP ANALYSIS}

The Sytykanskaya perovskite inclusion was liberated from its diamond host, mounted in epoxy, and polished for subsequent microbeam analysis. Backscattered electron imaging was carried out at the GSC using a Cambridge Instruments S360 scanning electron microscope, and a representative image of the grain is presented in Figure 1. Backscatter imaging revealed no obvious internal structural or compositional complexities, and texturally, offered no hint of age zonation within the grain.

Analytical protocols for in situ perovskite $\mathrm{U}-\mathrm{Pb}$ age determinations have recently been developed for the GSC's SHRIMP II ion microprobe, and are described in detail elsewhere (Hamilton et al., in prep.). Essential in this process was the assessment of a number of inhouse perovskite standards for suitability as ion probe $\mathrm{Pb} / \mathrm{U}$ isotope and $\mathrm{U}$, Th abundance reference materials.

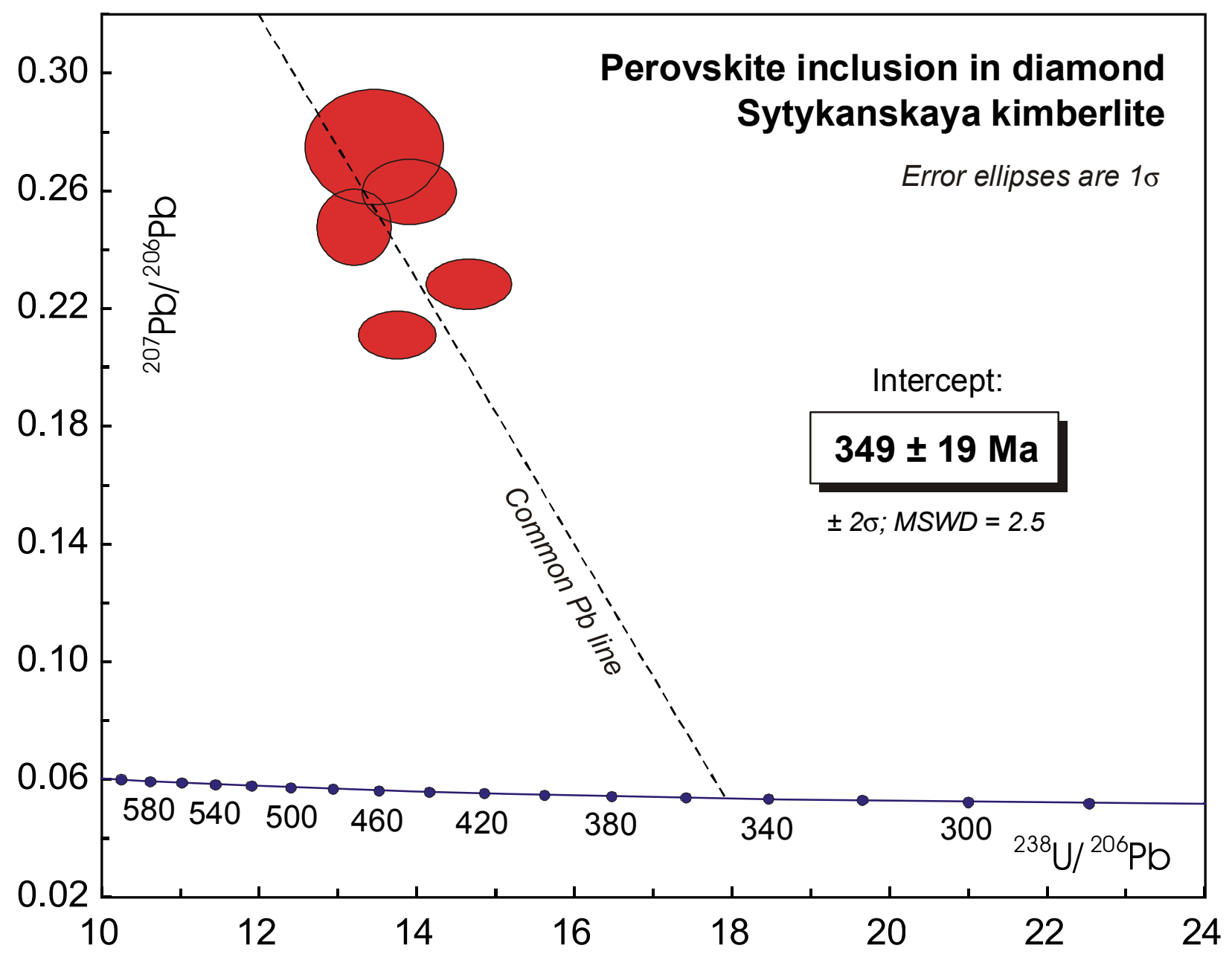

Figure 2: Tera-Wasserburg concordia plot. Uncorrected data. 
In the current study, instrumental $\mathrm{Pb} / \mathrm{U}$ fractionation was corrected by empirical reference to perovskite from the Schryburt Lake carbonatite complex of northwestern Ontario (Sage, 1988; Platt, 1994). Replicate analyses of this material by isotope dilution TIMS methods yield a weighted mean ${ }^{206} \mathrm{~Pb} /{ }^{238} \mathrm{U}$ age of $1080 \mathrm{Ma}$. Grains of this material were analyzed on the SHRIMP in parallel with the Sytykanskaya perovskite, using a primary oxygen beam with a sputter diameter of approximately 15 microns. Because of the size and irregular form of the sectioned Sytykanskaya grain, we were able to acquire data from a maximum of only five analytical spots during the session. Despite this, the minimally-destructive nature of SHRIMP analysis compared to techniques such as laser ablation means that the grain remains available for further trace element, isotopic, or other microanalytical studies.

Data for all five spot analyses, uncorrected for common $\mathrm{Pb}$, are presented in a Tera-Wasserburg plot in Figure 2. We interpret the distribution of the data to represent a reasonable fit to a simple mixing line between an estimated common $\mathrm{Pb}$ composition and a radiogenic end-member (on concordia) whose mean age is $349 \pm$ $19 \mathrm{Ma}(2 \sigma ; n=5, \mathrm{MSWD}=2.5)$. Using this method, the calculated fractional amount of total ${ }^{206} \mathrm{~Pb}$ that is common (i.e. non-radiogenic) $\mathrm{Pb}$ ranges from 14-32\%. Elemental abundances range from approximately 70$130 \mathrm{ppm}$ for $\mathrm{U}$, and 1200-2900 ppm for Th. Where determined, published concentrations for $\mathrm{U}$ and $\mathrm{Th}$ in kimberlitic perovskite are not dissimilar (e.g. Smith et al., 1994; Heaman and Mitchell, 1995; Kinny et al., 1995; 1997). A provisional $\mathrm{Th} / \mathrm{Pb}$ calibration made during this analytical session yielded a mean ${ }^{208} \mathrm{~Pb} /{ }^{232} \mathrm{Th}$ age for the perovskite inclusion that is within error of, but slightly less precise than, the 349 $\mathrm{Ma}{ }^{206} \mathrm{~Pb} /{ }^{238} \mathrm{U}$ age.

\section{DISCUSSION}

The ${ }^{206} \mathrm{~Pb} /{ }^{238} \mathrm{U}$ age of $349 \pm 19 \mathrm{Ma}$ for the single perovskite inclusion in diamond is identical, within error, of the $344 \mathrm{Ma}$ eruption age for the host Sytykanskaya pipe determined by conventional U-Pb methods on kimberlitic zircon (Davis et al., 1980). More recent $\mathrm{U}-\mathrm{Pb}$ age determinations on kimberlitic zircon and groundmass perovskite from other Yakutian kimberlites in the Daldyn-Alakit fields range from 344$367 \mathrm{Ma}$ (Kinny et al., 1997) and support the notion of a significant kimberlite emplacement event during this period.
The coexistence of chromite and olivine indicates a Ptype paragenesis for the diamond; hence, if the age represents the time of diamond formation it documents a young episode of P-type diamond growth in the Siberian lithosphere. This young age contrasts with the ancient, Archean ages for P-type diamonds indicated by Sm-Nd and Re-Os isotope systems (Richardson and Harris, 1997; Pearson et al., 1999a; 1999b). Possibly, the perovskite-bearing diamond from Sytykanskaya represents a minor, late phase of diamond growth, close to the time of kimberlite eruption. However, Naggregation evidence (Taylor et al., 1995; Bulanova, 1995) and elemental zoning studies of diamond inclusions (Shimizu and Sobolev, 1995) have suggested the possibility of significant diamond growth in the Siberian lithosphere close to the time of kimberlite eruption. Our U-Pb age determination would support this notion. Further work is needed on the REE composition and crystalline structure of this inclusion to more firmly establish its syngenetic versus epigenetic nature before we can conclude that it represents latestage diamond growth.

\section{REFERENCES}

Bristow, J.W., Barton, E.S., Compston, W., Williams, I.S., Smith, C.B., 1991. Determination of kimberlite and related-rock emplacement ages by ion-microprobe analysis of in situ perovskites. Unpublished abstract, $5^{\text {th }}$ IKC, Araxa, Brazil.

Bulanova, G.P., 1995. The formation of diamond. Jour. Geochem. Explor. 53, 1-23.

Burgess, R., Turner, G., Laurenzi, M., Harris, J.W., 1989. ${ }^{40} \mathrm{Ar} /{ }^{39} \mathrm{Ar}$ laser probe dating of individual clinopyroxene inclusions in Premiere eclogitic diamonds. Earth Planet. Sci. Lett. 94, 22-28.

Davis, G.L., Sobolev, N.V., Khar'kiv, A.D., 1980. New data on the age of Yakutian kimberlites obtained by the uranium-lead method on zircons. Dokl. Akad. Nauk SSSR 254, 175-179.

Hamilton, M.A., Stern, R.A., Kjarsgaard, B.A., 2003. Perovskite U-Th- $\mathrm{Pb}$ geochronology using SHRIMP ion probe mass spectrometry: technique and applications. In preparation.

Heaman, L.M., Mitchell, R.H., 1995. Constraints on the emplacement age of Yakutian province kimberlites from U-Pb perovskite dating. $6^{\text {th }}$ IKC Novosibirsk, Extended Abstracts, 223-224.

Kinny, P.D., Meyer, H.O.A., 1994. Zircon from the mantle: A new way to date old diamonds: Jour. Geol. 102, 475481.

Kinny, P.D., Griffin, B.J., Brakhfogel, F.F., 1995. SHRIMP $\mathrm{U}-\mathrm{Pb}$ ages of perovskite and zircon from Yakutian kimberlites. $6^{\text {th }}$ IKC Novosibirsk, Extended Abstracts, 275-276.

Kinny, P.D., Griffin, B.J., Heaman, L.M., Brakhfogel, F.F., Spetsius, Z.V., 1997. SHRIMP U-Pb ages of perovskite 
from Yakutian kimberlites. Russian Geol. Geophys. 38, 97-105.

Kopylova, M.G., Gurney, J.J. and Daniels, L.R.M., 1997. Mineral inclusions in diamonds from the River Ranch kimberlite, Zimbabwe. Contribs. Mineral. Petrol. 129, 366-384.

Meyer, H.O.A., 1987. Inclusions in diamonds. In: Nixon, P.H. (Ed.), Mantle Xenoliths. John Wiley and Sons, New York, NY, pp. 501-523.

Pearson, D.G., Shirey, S.B., Harris, J.W., Carlson, R.W., 1998. Sulfide inclusions in diamonds from the Koffiefontein kimberlite, S. Africa: Constraints on diamond ages and mantle Re-Os systematics. Earth Planet. Sci. Lett. 160, 311-326.

Pearson, D.G., Shirey, S.B., Bulanova, G.P., Carlson, R.W., Milledge, H.J., 1999a. Dating and paragenetic distinction of diamonds using the Re-Os isotope system: Application to some Siberian diamonds. Proc. $7^{\text {th }}$ IKC, Cape Town, 1998. Red Roof Design, Cape Town, South Africa, pp. 637-643.

Pearson, D.G., Shirey, S.B., Bulanova, G.P., Carlson, R.W., Milledge, H.J., 1999b. Re-Os isotope measurements of single sulfide inclusions in a Siberian diamond and its nitrogen aggregation systematics. Geochim. Cosmochim. Acta 63, 703-711.

Platt, R.G., 1994. Perovskite, loparite and Ba-Fe hollandite from the Schryburt Lake carbonatite complex, northwestern Ontario, Canada. Min. Mag. 58, 49-57.

Phillips, D., Onstott, T.C., Harris, J.W., 1989. ${ }^{40} \mathrm{Ar} /{ }^{39} \mathrm{Ar}$ laserprobe dating of diamond inclusions from Premiere kimberlite. Nature 340, 460-462.

Richardson, S.H., 1986. Latter-day origin of diamonds of eclogitic paragenesis. Nature 322, 623-626.

Richardson, S.H., Harris, J.W., 1997. Antiquity of peridotitic diamonds from the Siberian craton. Earth Planet. Sci. Lett. 151, 271-277.

Richardson, S.H., Erlank, A.J., Harris, J.W., Hart, S.R., 1990. Eclogitic diamonds of Proterozoic age from Cretaceous kimberlites. Nature 346, 54-56.

Richardson, S.H., Gurney, J.J., Erlank, A.J., Harris, J.W., 1984. Origin of diamonds in old enriched mantle. Jour. Petrol. 27, 155-196.

Richardson, S.H., Harris, J.W., Gurney, 1993. Three generations of diamonds from old continental mantle. Nature 366, 256-258.

Sage, R.P., 1988. Geology of carbonatite-alkalic rock complexes in Ontario: Schryburt Lake Carbonatite Complex, District of Kenora. Ont. Geol. Surv. Study $50,43 \mathrm{pp}$.

Shimizu, N., Sobolev, N.V., 1995. Young peridotitic diamonds from the Mir kimberlite pipe. Nature 375, 394-397.

Smith, C.B., Clark, T.C., Barton, E.S., Bristow, J.W., 1994. Emplacement ages of kimberlite occurrences in the Prieska region, southwest border of the Kaapvaal Craton, South Africa. Chem. Geol. 113, 149-169.

Spetsius, Z.V., Belousova, E.A., Griffin, W.L., O'Reilly, S.Y., Pearson, N.J., 2002. Archean sulfide inclusions in Paleozoic zircon megacrysts from the Mir kimberlite, Yakutia: implications for the dating of diamonds. Earth Planet. Sci. Lett. 199, 111-126.
Taylor, L.A., Milledge, H.J, Bulanova, G., Snyder, G.A., Keller, R.A., 1998. Metasomatic eclogitic diamond growth: Evidence from multiple diamond inclusions. Int. Geol. Rev. 40, 595-612.

Taylor, W.R., Bulanova, G.P., Milledge, H.J., 1995. Quantitative nitrogen aggregation study of some Yakutian diamonds: constraints on the growth, thermal and deformation history of peridotitic and eclogitic diamonds. $6^{\text {th }}$ IKC Novosibirsk, Extended Abstracts, 608-610.

Contact: MA Hamilton, 605 Island Park Cres., Ottawa, ON, Canada K1Y 3P4, E-mail: mahamilton@rogers.com

Note: we wish to acknowledge the generous help of Vince Vertolli and Bob Ramik of the Royal Ontario Museum in supplying us with a specimen from the Schryburt Lake carbonatite complex. 